\title{
Recovery of MRSA and Clostridium difficile in an ICU ward
}

\author{
A Ram ${ }^{1 *}$, AP Gibb², K Templeton², A Holmes ${ }^{3}$, D Swann², CM Taylor ${ }^{1}$ \\ From International Conference on Prevention \& Infection Control (ICPIC 2011) \\ Geneva, Switzerland. 29 June - 2 July 2011
}

\section{Introduction / objectives}

The role of the hospital environment as a reservoir of infection is poorly understood. Therefore, baseline levels of MRSA (methicillin-resistant Staphylococcus aureus) and Clostridium difficile contamination on surfaces were determined in an ICU ward. The aim was to determine whether contamination differs at certain times of the day, if recovery of pathogens is influenced by total background contamination and to what extent cleaning affects contamination levels.

\section{Methods}

Sampling occurred in an 18 bed ICU ward on regular days for one month. Surfaces were sampled from patient and non-patient areas, morning and afternoon, to detect total viable counts (TVC), MRSA and C. difficile using contact plates and swabs. Multi-locus variable number tandem repeat fingerprinting (MLVF) was performed on selected isolates to determine relationship of MRSA from patients and environment. Statistical analyses were carried out using non-parametric tests.

\section{Results}

Data showed MRSA was recovered from $32 \%$ and C. difficile recovered from $27 \%$ of surfaces. All surfaces tested were contaminated with no significant difference in TVC regardless of time of sampling. MLVF data suggested transfer of MRSA from patient to environment rather than the converse.

\section{Conclusion}

Cleaning was scheduled in the morning however, whether surfaces were re-contaminated after cleaning or whether cleaning was ineffective remains to be established and requires more investigation. Therefore bacteria were

${ }^{1}$ Edinburgh Napier University, Edinburgh, UK

Full list of author information is available at the end of the article detected throughout the surveillance period providing data on baseline levels of MRSA and C. difficile on surfaces. Bacterial contamination remains at easily detectable levels despite regular cleaning so ward cleaning protocols may need to be revised.

\section{Disclosure of interest}

None declared.

Author details

${ }^{1}$ Edinburgh Napier University, Edinburgh, UK. ${ }^{2}$ Royal Infirmary of Edinburgh, Edinburgh, UK. ${ }^{3}$ The University of Edinburgh, Edinburgh, UK.

Published: 29 June 2011

doi:10.1186/1753-6561-5-S6-P185

Cite this article as: Ram et al:: Recovery of MRSA and Clostridium difficile in an ICU ward. BMC Proceedings 2011 5(Suppl 6):P185.

\section{Biomed Central}

(c) 2011 Ram et al; licensee BioMed Central Ltd. This is an open access article distributed under the terms of the Creative Commons Attribution License (http://creativecommons.org/licenses/by/2.0), which permits unrestricted use, distribution, and reproduction in any medium, provided the original work is properly cited.

Submit your next manuscript to BioMed Central and take full advantage of:

- Convenient online submission

- Thorough peer review

- No space constraints or color figure charges

- Immediate publication on acceptance

- Inclusion in PubMed, CAS, Scopus and Google Scholar

- Research which is freely available for redistribution 